\title{
CHANGES IN HOUSING AVAILABILITY INDICATOR IN SELECTED POLISH CITIES IN THE YEARS 2006 to 2018
}

\author{
Marta Martyniak ${ }^{1}$ \\ ${ }^{1}$ University of Economics, Katowice, Poland, marta.martyniak@ue.katowice.pl, ORCID: 0000-0003-2619-9081
}

\begin{abstract}
Research purpose. Housing availability indicator shows the area of residential real estate possible to purchase for the average monthly wage in the enterprise sector. The research carried out in this paper is aimed at determining the current level of housing availability indicator and its detailed analysis, taking into account the dynamics of changes in 2006 to 2018. This analysis will be carried out for primary and secondary market for selected Polish cities.
\end{abstract}

Design/Methodology/Approach. Calculations were based on the average transaction prices obtained from the transactional database of residential real estate of the National Bank of Poland and the value of the average monthly remuneration in the enterprise sector obtained partly from statistical data and official journals of the Central Statistical Office.

Findings. The analysis shows that the indicator of housing availability in Poland, despite the visible upward trend, is at a very low level, placing Warsaw at the first place. In addition, the extension of the analysis to the division of the housing market into the primary and secondary market provided more information about shaping the housing availability indicator. Whereas in the primary market in individual cities its value was at a similar level, the secondary market was subject to greater fluctuations.

Originality/Value/Practical implications. This paper is of practical nature. Due to the asymmetry of information on the Polish real estate market, especially regarding housing prices, knowledge about the value of the housing availability indicator in Poland may be exceptionally valuable, especially for people interested in the housing market, including individual investors and market practitioners, as an auxiliary source of information in purchasing decisions of households.

Keywords: Housing availability indicator; Real estate market; Housing market.

JEL codes: R20; R31.

\section{Introduction}

The most important function of residential real estate for households is to meet housing needs. Not only is an apartment a place to perform basic life activities, but it also creates conditions for the creation of a new social unit which is a family (Kusińska, 2009). It also plays the role of the foundation in satisfying the basic human needs, without which it is impossible to fully satisfy the needs of a higher order (Zalega, 2010). Therefore, issues related to the availability of housing are particularly important in two dimensions: first, households and second, in the context of housing policy of the state.

The housing market in Poland is characterized by asymmetry of information, especially regarding real estate prices. This means that the typical household has a low knowledge about the formation of housing prices, as well as about the dynamics of their changes. Research housing availability index will provide new information about the residential real estate market in Poland. It seems reasonable to adopt a division into the primary and secondary market. So far, literature of the subject in this field is selective and often out of date (no literature references taking into account the latest data). The aim of this paper is to determine the current level of the housing availability indicator and its detailed analysis, taking into account the dynamics of index changes in years 2006 to 2018. The thesis is defined as follows: The secondary market is characterized by a higher housing availability and lower fluctuations in this indicator. The calculations were based on data collected from the Polish National Bank (NBP) and Polish Central Statistical Office (GUS). The analysis shows that there are differences between the housing 
availability index in the primary and secondary market. The study also showed discrepancies in the context of individual cities.

\section{Literature Review}

The concept of housing availability is differently defined in the literature of the subject. The NBP uses in its analysis the concept of housing availability indicator defined as "a measure of potential availability to purchase housing space at the transaction price for an average wage in the enterprise sector in a particular city. It expresses the number of square metres of housing that can be purchased for an average wage in the enterprise sector in a particular city, at an average transaction price in a particular market" (J. Łaszek et al., 2017). It is a strictly income approach, covering two criteria: average transaction prices and average household income. The disadvantage of this indicator in Poland is that the GUS does not disclose data concerning an average wage in the enterprise sector in a particular city, just only for the whole country. The results will therefore not reflect the exact situation in a particular city, but only an approximate value. However, this indicator is popular in many real estate reports and is simple to use. In addition, even the approximate value of the indicator for individual cities is an important information for households striving to satisfy housing needs.

A similar definition is presented in the AMRON-SARFiN reports as quarterly changes in the availability of housing for an example of a family consisting of two working persons and an older child (2018). Housing availability index can also be calculated as a ratio of household income (or as alternative residual income) and housing expenditures (Radzimski, 2014). In a different perspective, housing availability is "the challenge of living in the future, and its non-housing expenditures, on the other, within the constraints of its income" (Stone, 2006).

These definitions are limited only to the interpretation of the category of income. In the literature of the subject, we can also find a different approach to housing availability in the form of accessible housing construction (reference to the English housing system - affordable housing). This term is determined for three phenomena: apartments or houses located in the housing market, without a price turning point; housing premises for homeless people; apartments or houses for which medium-affluent households can afford, usually financed with some help from the state or municipality (Twardoch, 2009). In this approach, housing availability mainly concerns issues related to the state's housing policy.

In Poland, there is a strong desire to own a residential property. According to the NBP data from 2015, 77.4 percent of households own the main residence, which is one of the highest results compared to EU countries (Narodowy Bank Polski, 2015). Most Polish households are forced to purchase a residential property using a mortgage loan. Accordingly, among the relevant factors measuring housing availability is the interest rate of the central bank. The interest rate is an important criterion for assessing creditworthiness and determines the availability of housing for households with low incomes. Similar features are also met by the availability of loan-financed housing. The availability of housing is also dependent on their current supply and the availability of government programs created to supporting the purchase of residential property (Matel \& Marcinkiewicz, 2017). In recent years, several such programs have been created in Poland, and the opinion about them is varied (Gołębiewska \& Prokopowicz 2017; Groeger 2016).

The current state of research on the housing availability index in Poland largely represents reports and analysis of the housing market. In the AMRON-SARFiN reports, the housing availability index is presented for data from 2005 to 2018 in the entire Poland, without any division into primary and secondary market (AMRON-SARFiN, 2018). NBP research also does not include such a division (Narodowy Bank Polski, 2015). In both of these studies published quarterly for several years, the housing availability indicator has only information purposes and is not subject to further analysis.

In addition to market analysis, the housing availability index was the subject of research; however, it does not cover a longer period of time. Matel and Marcinkiewicz (2017) analysed housing availability in Polish voivodeship cities only for the year 2015. Radzimski investigated housing availability only for the year 2011, however, in a much broader context - the relationship between the spatial differentiation of subsidized mortgage loans and that of housing affordability. It also indicates that the housing 
availability index can be counted in two ways: first, in a similar way as NBP, that is, as salary/housing price index and, second, as household income/housing price index (Radzimski, 2014).

\section{Methodology}

This paper adopts the interpretation of the housing availability indicator presented by Łaszek et al. for the NBP. First of all, this indicator is popular in many reports and studies on the real estate market, and second, it is easy to interpret. This means research results will be accessible not only for professionals and real estate market researchers, but also for the average household. Moreover, even the approximate value of the indicator for individual cities is an important information about the situation on the local real estate market. Accordingly, the following formula was adopted for the calculation of the housing availability index:

$$
\text { Housing availability }=\frac{\text { average wage in the enterprise sector }}{\text { average transaction price in a particular market }}
$$

The higher the score index, the higher the availability of housing for households. In the literature of the subject, there is no interval by which its values can be assigned to low or high. Interpretations should be compared to other values, for example, from a different period or different area.

For the calculation were used the average transaction prices from the seven largest Polish cities (capitals of provinces and Warsaw) obtained from the database of transaction prices of residential real estate of the NBP and the average monthly remuneration in the enterprise sector obtained partly from statistical data of the Polish Central Statistical Office and their official journals.

The calculations were made for the entire set of available data, that is, for the years 2006 to 2018, broken down into primary and secondary market. It was necessary to average the value of the average monthly remuneration in the enterprise sector to quarterly values in order to be able to compare the values of transaction prices and income. The results were presented on an annual basis to help recipients analyse and compare data.

\section{Results}

First, the housing availability index was calculated for the selected seven Polish cities: Warszawa (Warsaw) as the capital agglomeration and Gdańsk, Katowice, Kraków (Cracow), Łódź, Poznań, and Wrocław. The largest cities in Poland were chosen because they are considered the most developed. The values of the housing availability index, broken down into the primary and secondary market, are presented in Tables 1 and 2 .

Table 1. Housing availability index in the primary market in selected Polish cities in 2006 to 2018 (in $\mathbf{~ m}^{2}$ ) (Source: own calculations)

\begin{tabular}{|c|c|c|c|c|c|c|c|}
\hline Year & Gdańsk & Katowice & Cracow & Lódź & Poznań & Warsaw & Wrocław \\
\hline 2006 & 0.64 & 0.75 & 0.39 & 0.85 & 0.66 & 0.46 & 0.78 \\
\hline 2007 & 0.44 & 0.58 & 0.37 & 0.58 & 0.45 & 0.37 & 0.49 \\
\hline 2008 & 0.47 & 0.58 & 0.41 & 0.61 & 0.45 & 0.38 & 0.59 \\
\hline 2009 & 0.59 & 0.67 & 0.47 & 0.67 & 0.53 & 0.44 & 0.64 \\
\hline 2010 & 0.63 & 0.70 & 0.50 & 0.70 & 0.53 & 0.44 & 0.60 \\
\hline 2011 & 0.65 & 0.76 & 0.52 & 0.73 & 0.57 & 0.48 & 0.61 \\
\hline 2012 & 0.68 & 0.76 & 0.57 & 0.82 & 0.65 & 0.55 & 0.67 \\
\hline 2013 & 0.67 & 0.79 & 0.64 & 0.85 & 0.64 & 0.53 & 0.69 \\
\hline 2014 & 0.69 & 0.82 & 0.67 & 0.87 & 0.65 & 0.54 & 0.68 \\
\hline 2015 & 0.69 & 0.83 & 0.67 & 0.88 & 0.66 & 0.55 & 0.68 \\
\hline 2016 & 0.67 & 0.85 & 0.67 & 0.90 & 0.68 & 0.56 & 0.70 \\
\hline 2017 & 0.68 & 0.87 & 0.68 & 0.91 & 0.71 & 0.59 & 0.71 \\
\hline 2018 & 0.65 & 0.88 & 0.70 & 0.91 & 0.72 & 0.58 & 0.72 \\
\hline
\end{tabular}


Table 2. Housing availability index in the secondary market in selected Polish cities in 2006 to 2018 (in $\mathbf{~ m}^{2}$ ) (Source: own calculations)

\begin{tabular}{|c|c|c|c|c|c|c|c|}
\hline Year & Gdańsk & Katowice & Cracow & Lódź & Poznań & Warsaw & Wroclaw \\
\hline 2006 & 0.68 & 1.30 & 0.47 & 1.34 & 0.75 & 0.41 & 0.56 \\
\hline 2007 & 0.51 & 0.90 & 0.42 & 0.76 & 0.53 & 0.33 & 0.47 \\
\hline 2008 & 0.53 & 0.84 & 0.48 & 0.80 & 0.54 & 0.36 & 0.54 \\
\hline 2009 & 0.58 & 0.94 & 0.55 & 0.88 & 0.63 & 0.40 & 0.58 \\
\hline 2010 & 0.60 & 0.96 & 0.55 & 0.88 & 0.63 & 0.40 & 0.57 \\
\hline 2011 & 0.66 & 1.04 & 0.57 & 0.94 & 0.67 & 0.46 & 0.61 \\
\hline 2012 & 0.73 & 1.11 & 0.60 & 1.07 & 0.72 & 0.50 & 0.69 \\
\hline 2013 & 0.78 & 1.19 & 0.66 & 1.12 & 0.77 & 0.55 & 0.76 \\
\hline 2014 & 0.80 & 1.17 & 0.68 & 1.16 & 0.79 & 0.54 & 0.77 \\
\hline 2015 & 0.79 & 1.19 & 0.67 & 1.22 & 0.82 & 0.56 & 0.79 \\
\hline 2016 & 0.78 & 1.20 & 0.73 & 1.28 & 0.82 & 0.58 & 0.81 \\
\hline 2017 & 0.75 & 1.24 & 0.73 & 1.23 & 0.84 & 0.58 & 0.80 \\
\hline 2018 & 0.71 & 1.19 & 0.74 & 1.17 & 0.84 & 0.59 & 0.79 \\
\hline
\end{tabular}

The results presented in Tables 1 and 2 should be interpreted as follows: In 2018, for the average monthly wage in the enterprise sector, the household could purchase $0.65 \mathrm{~m}^{2}$ of usable floor space on the primary market and $0.71 \mathrm{~m}^{2}$ on the secondary market. In 2007, a drop in the index is visible, which reflects changes in the local market caused by the crisis in the United States. Transaction prices significantly increased, which, with unchanged incomes, resulted in a decrease in housing availability. However, it should be noted that both the primary market and the secondary market after the crisis show an upward trend, and its increase in value is different for each market.

The values of the housing availability index have been deliberately placed in two separate tables in order to be able to consider the primary and secondary market separately. Interesting changes are presented in the primary market in Cracow and Warsaw. Cracow until 2012 was characterized by lower availability of housing than the other markets. In subsequent years, the index increased, matching the values presented in other markets. This may be testified by the development of the local developer market. However, housing availability index in Warsaw, despite the growing trend, remains low in comparison to other cities.

The secondary market of the same cities was subject to slight fluctuations in the index and reflects similar changes as the primary market. It should also be noted that the secondary market is generally characterized by higher housing availability than the primary market. In order to be able to analyse in detail the changes in housing availability between the primary and secondary market, they were compared (Table 3).

Table 3. Changes in the housing availability index on the primary and secondary market in selected Polish cities in 2006 to 2018 (in $\mathrm{m}^{2}$ ) (Source: own calculations)

\begin{tabular}{|l|l|l|l|l|l|l|l|}
\hline Year & Gdańsk & Katowice & \multicolumn{1}{|c|}{ Cracow } & \multicolumn{1}{c|}{ Lódź } & \multicolumn{1}{|c|}{ Poznań } & \multicolumn{1}{|c|}{ Warsaw } & Wrocław \\
\hline 2006 & -0.04 & -0.55 & -0.08 & -0.50 & -0.09 & 0.05 & 0.22 \\
\hline 2007 & -0.06 & -0.32 & -0.05 & -0.18 & -0.08 & 0.03 & 0.03 \\
\hline 2008 & -0.06 & -0.25 & -0.08 & -0.19 & -0.09 & 0.02 & 0.05 \\
\hline 2009 & 0.01 & -0.27 & -0.08 & -0.21 & -0.09 & 0.04 & 0.07 \\
\hline 2010 & 0.02 & -0.26 & -0.05 & -0.18 & -0.10 & 0.03 & 0.03 \\
\hline 2011 & -0.01 & -0.28 & -0.04 & -0.22 & -0.10 & 0.02 & 0.00 \\
\hline 2012 & -0.05 & -0.35 & -0.04 & -0.25 & -0.07 & 0.04 & -0.02 \\
\hline 2013 & -0.11 & -0.40 & -0.02 & -0.27 & -0.13 & -0.02 & -0.07 \\
\hline 2014 & -0.11 & -0.35 & -0.01 & -0.29 & -0.15 & 0.00 & -0.09 \\
\hline 2015 & -0.10 & -0.35 & 0.00 & -0.34 & -0.16 & -0.01 & -0.11 \\
\hline 2016 & -0.10 & -0.35 & -0.06 & -0.38 & -0.14 & -0.02 & -0.11 \\
\hline 2017 & -0.07 & -0.37 & -0.05 & -0.32 & -0.12 & 0.01 & -0.09 \\
\hline 2018 & -0.06 & -0.30 & -0.05 & -0.26 & -0.13 & -0.01 & -0.07 \\
\hline
\end{tabular}


Negative values presented in Table 3 indicate how much square metre the availability of housing is higher on the secondary market than in the primary market. The biggest differences are in the market city of Katowice and Łódź, where in 2006 the difference amounted to $0.55 \mathrm{~m}^{2}$ and $0.50 \mathrm{~m}^{2}$ (the biggest differences are italicized). After 12 years, this difference has almost halved, but the value of the index is still high. This means that the greater availability of housing in both cities on the secondary market may be related to the low activity of developers and a high difference in transaction prices (about 200 to $250 € / 1 \mathrm{~m}^{2}$ ). From the presented results it is clear that the availability of housing in Warsaw at the primary and secondary market is subject to very low volatility, and over the years has remained at a constant level. Housing market in the capital of Poland can therefore be considered as the best developed.

This study also carried out the dynamics of changes in the availability of housing in two variants: with reference to the base year 2006 (Fig. 1) and the previous year (Fig. 2). This study is also divided into the primary and secondary market.

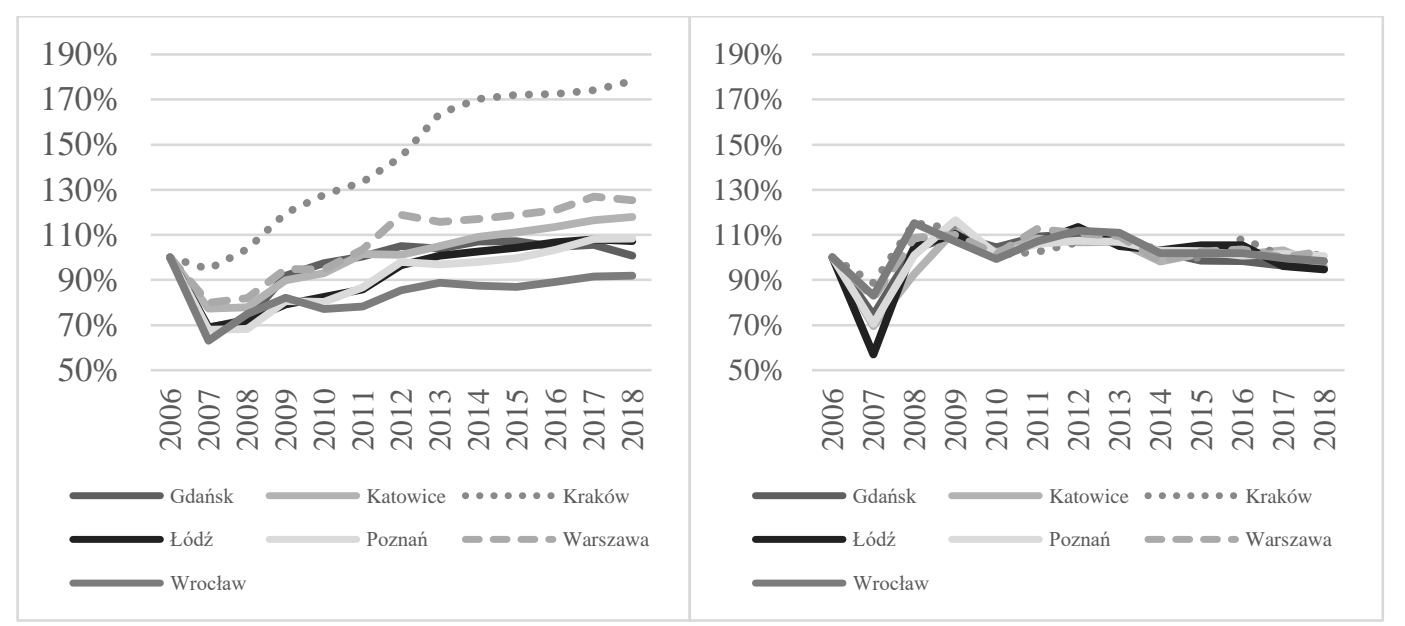

Fig. 1. The dynamics of housing availability indicator over time in relation to the base year 2006 (left: primary and right: secondary market) (Source: own calculations)

During the conducted analysis to the base year 2006, significant differences were noticed. On the primary market, the highest dynamics can be seen in Cracow housing market, which has almost doubled. A high change can also be noticed in Warsaw; however, compared to Cracow, it is half lower. This value can be regarded rather as similar to the rest of the primary housing market in Poland. On the other hand, the change in the index on the secondary market seems to have stabilized in the analysed period. There are no significant fluctuations compared to the primary market. In addition, the dynamics on both markets oscillate at a similar level (except the case of Cracow).

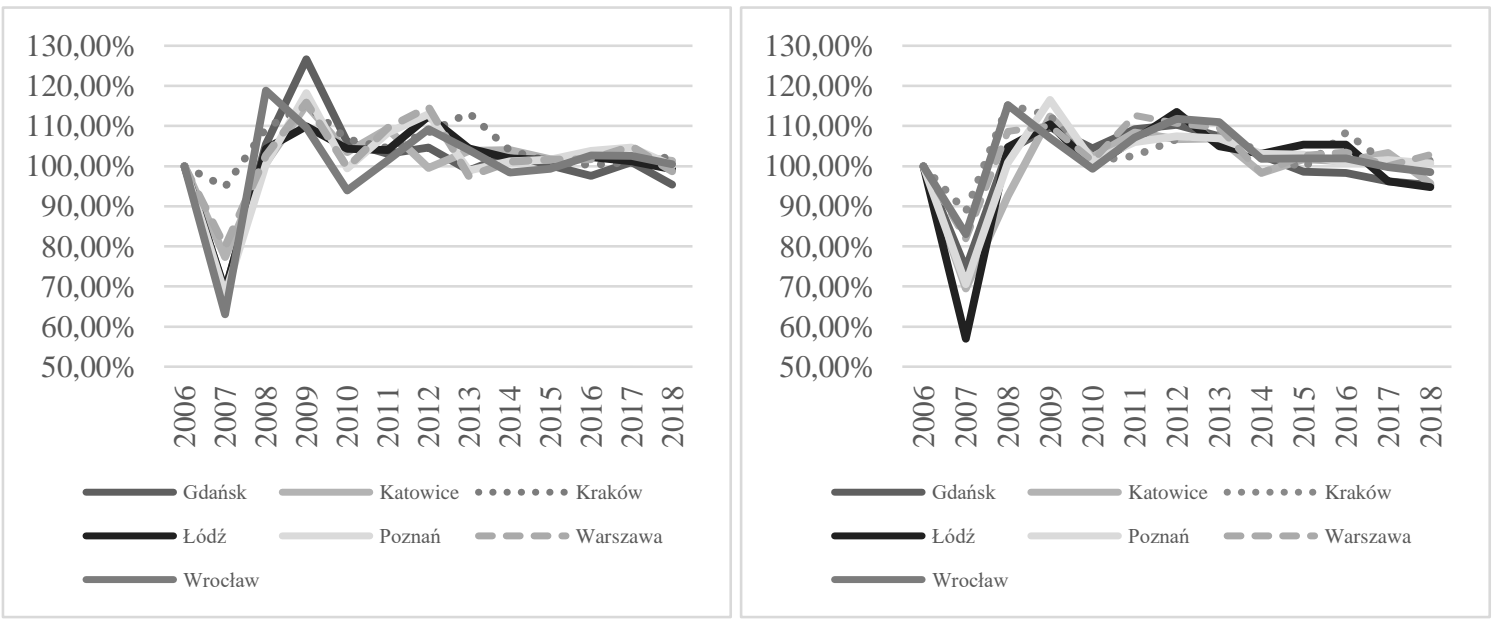

Fig. 2. The dynamics of housing availability over time in relation to the previous year (left: primary and right: secondary market) (Source: own calculations) 
The test dynamics of the phenomenon in relation to the previous year (Fig. 2) were also examined. In this case both markets are characterized by similar dynamics. However, fluctuations in the primary market were slightly higher than fluctuations in the secondary market. Since 2014, in both cases the dynamic fluctuates around a similar level. Therefore, it can be assumed that changes in the housing availability indicator in recent years are stable and in the current market conditions, it may be assumed that they will continue to develop at a similar level.

The results regarding changes in the housing availability index in the primary and secondary market can also be presented in a different form, more accessible for the average household. Using data on the value of the housing availability indicator and the average usable floor space of one apartment in the analysed period, it is possible to calculate how many years the household should save to be able to buy its own property. Table 4 shows how many years a household needs to save in order to purchase residential real estate on the primary market or secondary market. It was assumed that the household wants to buy an apartment with an average usable area for the period under review (according to GUS data) and that it will allocate the entire monthly income for this purpose.

Table 4. Period during which the household will be able to buy own property, assuming that it will spend the entire average monthly income (in years) (Source: own calculations)

\begin{tabular}{|c|c|c|c|c|c|c|c|c|c|c|c|c|}
\hline \multirow[b]{2}{*}{ City } & Year & 2006 & 2007 & 2008 & 2009 & 2010 & 2011 & 2012 & 2013 & 2014 & 2015 & 2016 \\
\hline & $\begin{array}{c}\text { Average } \\
\text { usable floor } \\
\text { area of a } \\
\text { residential } \\
\text { building } \\
\end{array}$ & $\begin{array}{c}69.5 \\
\mathrm{~m}^{2}\end{array}$ & $\begin{array}{c}69.8 \\
\mathrm{~m}^{2}\end{array}$ & $\begin{array}{c}70.2 \\
\mathrm{~m}^{2}\end{array}$ & $\begin{array}{c}70.5 \\
\mathrm{~m}^{2}\end{array}$ & $\begin{array}{c}72.3 \\
\mathrm{~m}^{2}\end{array}$ & $\begin{array}{c}72.6 \\
\mathrm{~m}^{2}\end{array}$ & $\begin{array}{c}72.8 \\
\mathrm{~m}^{2}\end{array}$ & $\begin{array}{c}73.1 \\
\mathrm{~m}^{2}\end{array}$ & $\begin{array}{c}73.4 \\
\mathrm{~m}^{2}\end{array}$ & $\begin{array}{c}73.6 \\
\mathrm{~m}^{2}\end{array}$ & $\begin{array}{c}73.8 \\
\mathrm{~m}^{2}\end{array}$ \\
\hline \multirow[t]{2}{*}{ Gdańsk } & PM & 9.0 & 13.1 & 12.5 & 9.9 & 9.6 & 9.4 & 9.0 & 9.1 & 8.9 & 8.9 & 9.1 \\
\hline & SM & 8.5 & 11.5 & 11.1 & 10.2 & 10.0 & 9.2 & 8.4 & 7.8 & 7.6 & 7.8 & 7.9 \\
\hline \multirow[t]{2}{*}{ Katowice } & $\mathrm{PM}$ & 7.7 & 10.0 & 10.0 & 8.7 & 8.6 & 7.9 & 8.0 & 7.7 & 7.5 & 7.4 & 7.2 \\
\hline & SM & 4.5 & 6.4 & 7.0 & 6.3 & 6.3 & 5.8 & 5.5 & 5.1 & 5.2 & 5.2 & 5.1 \\
\hline \multirow{2}{*}{ Cracow } & $\mathrm{PM}$ & 14.8 & 15.7 & 14.4 & 12.6 & 12.1 & 11.6 & 10.7 & 9.5 & 9.2 & 9.1 & 9.1 \\
\hline & SM & 12.2 & 13.8 & 12.1 & 10.8 & 10.9 & 10.7 & 10.0 & 9.3 & 9.0 & 9.1 & 8.4 \\
\hline \multirow{2}{*}{ Lódź } & $\mathrm{PM}$ & 6.9 & 10.0 & 9.6 & 8.8 & 8.6 & 8.3 & 7.4 & 7.2 & 7.0 & 7.0 & 6.8 \\
\hline & SM & 4.3 & 7.6 & 7.3 & 6.7 & 6.8 & 6.4 & 5.7 & 5.4 & 5.3 & 5.0 & 4.8 \\
\hline \multirow{2}{*}{ Poznań } & PM & 8.8 & 13.0 & 13.0 & 11.0 & 11.4 & 10.6 & 9.4 & 9.5 & 9.4 & 9.3 & 9.0 \\
\hline & SM & 7.7 & 10.9 & 10.9 & 9.4 & 9.5 & 9.0 & 8.4 & 7.9 & 7.7 & 7.5 & 7.5 \\
\hline \multirow{2}{*}{ Warsaw } & PM & 12.5 & 15.8 & 15.5 & 13.4 & 13.8 & 12.7 & 11.1 & 11.4 & 11.3 & 11.2 & 11.0 \\
\hline & SM & 14.2 & 17.4 & 16.1 & 14.7 & 14.9 & 13.3 & 12.0 & 11.0 & 11.3 & 11 & 10.7 \\
\hline \multirow{2}{*}{ Wroclaw } & PM & 7.4 & 11.8 & 10.0 & 9.2 & 10.0 & 9.9 & 9.1 & 8.8 & 9.0 & 9.0 & 8.8 \\
\hline & SM & 10.3 & 12.5 & 10.9 & 10.2 & 10.5 & 9.9 & 8.9 & 8.0 & 7.9 & 7.8 & 7.6 \\
\hline
\end{tabular}

PM, primary market; SM, secondary market.

Due to the lack of data on the average usable area of dwellings in 2017 and 2018 these years are not included in the analysis. Table 4 shows the lowest value and the highest value (italics, Łódź, Warsaw). Interestingly, both fall in the years 2006 and 2007, therefore a period similar to the crisis in the U.S. housing market. When comparing the extreme years, 2006 and 2016, in many cases it can be noticed that, despite the upward trend in the housing availability indicator, the result in many cases remains at a similar level (Gdańsk, Katowice, Łódź). The exception is Cracow and Warsaw, where the analysed value has fallen.

\section{Conclusions}

Housing availability in both the primary and secondary market (except for the crisis in the United States, 2007) shows an upward trend, and the increase in its value varies for each city. In both cases, Warsaw has the lowest housing availability and the lowest level of index fluctuations. It can be considered that the value of this index is stable. Until 2012, Cracow was also characterized by lower housing availability than other markets. The conducted analysis also showed that the secondary market of selected cities is generally characterized by higher housing availability than the primary market. The biggest differences 
between housing availability index of the primary and secondary market exist for the city of Katowice and Łódź. The accepted thesis was therefore proved.

Analysis of the dynamics of changes in the value of the indicator in relation to the base year 2006 on the primary market showed significant differences for the city of Cracow. In this case, it has almost doubled. Such high growth should be associated with the revival of the development market and its high efficiency in creating a new housing stock increase. In other cases, the analysis of the index of dynamics did not show any significant changes.

The study of the value of the housing availability index in Poland, broken down into the primary and secondary market, provided valuable information about its shaping and dynamics of change. It is widely known that high housing availability is a desirable situation for both households and the state's housing policy. Therefore, the information obtained in this paper is an important contribution to research on the housing market. The upward trend in housing availability should be identified with, above all, the constant improvement in income conditions of households and the development of the market in Poland.

In the future, research on the level of housing availability index in Poland should be continued, taking into account changes in the business environment, for example, the impact of government programs subsidizing the purchase of their own homes. The study could also be extended to compare the availability of housing for another city in Poland, as well as with other countries.

\section{References}

Gołębiowska, A., \& Prokopowicz, D. (2017). National Housing Program Of The Main Strategic And Program Document For The Current State Residential Policy Of The State, International Journal of New Economics and Social Sciences. 2(6), 305-316.

Groeger, L. (2016)., Programy wspierania budownictwa mieszkaniowego w Polsce $i$ ich wplyw na rynek nieruchomości mieszkaniowych, [Accessed 20.03.2019]. Available from Internet: https://www.czasopisma.uni. lodz.pl/space/article/viewFile/1460/1123.

Kusińska, A. (2009). Zmiany w sferze konsumpcji i ich uwarunkowania w latach 1989-2009. Handel Wewnętrzny, (4-5), 38.

Łaszek, J., Augustyniak, H., Olszewski, K., Waszczuk, J., \& Widłak, M. (2017). Information on home prices and the situation in the housing and commercial real estate market in Poland in 2016 Q4. [Accessed 20.03.2019]. Available from Internet: https://www.nbp.pl/en/publikacje/inne/real_estate_market_2016_Q4.pdf

Matel, A., \& Marcinkiewicz, J. (2017). Analiza dostępności mieszkań w miastach wojewódzkich polski z wykorzystaniem metody TOPSIS. Research Papers of the Wroclaw University of Economics/Prace Naukowe Uniwersytetu Ekonomicznego we Wroclawiu, (475), 170-182.

Narodowy Bank Polski, Departament Stabilności Finansowej (2015). Zasobność gospodarstw domowych w Polsce, Z. Raport z badania pilotażowego 2014 r. [Accessed 20.03.2019]. Available from Internet: https://www.nbp.pl/aktualnosci/wiadomosci_2015/Raport_BZGD_2014.pdf

Official Journals of the Polish Central Statistical Office (GUS), [Accessed 20.02.2019]. Available from Internet: https://dziennikigus.stat.gov.pl/dzienniki-urzedowe-gus/2018,arch.html

Radzimski, A. (2014). Subsidized mortgage loans and housing affordability in Poland. GeoJournal, (79), 473, 485.

Raport AMRON-SARFiN. (2018). Ogólnopolski raport o kredytach mieszkaniowych i cenach transakcyjnych 2/2018. [Accessed 25.03.2019]. Available from Internet: https://zbp.pl/public/repozytorium/wydarzenia/images/ sierpien_2018/Raport_AMRON-SARFiN_Nr_2_2018_Pl.pdf

Stone, M. E. (2006). What is housing affordability? The case for the residual income approach. Housing policy debate, (17), 151-179.

Twardoch, A. (2009). Dostępne budownictwo mieszkaniowe. Architecturae et Artibus, 1, 77.

Zalega, T. (2010). Uwarunkowania zaspokojenia potrzeb w zakresie mieszkania i jego wyposażenia w gospodarstwach domowych wysokodochodowych. Master of Business Administration, (18), 63. 